\title{
3. The Australian Public Service: new agendas and reform
}

\author{
JOHN HALLIGAN
}

A change of federal government can be expected to produce new directions for the Australian Public Service (APS), and this is more likely after lengthy periods of opposition provide the incubation for new policy and the impetus for initiating change. The 1972, 1983, 1996 and 2007 turnovers stand out as significant turning points for the APS. ${ }^{1}$

Kevin Rudd's first term was notable for the change of focus expected of a new government, and the distancing and differentiating of public governance and administration from that of the Howard government (cf. Halligan 2008a). But the aspirations were much higher - to anticipate the long-term challenges and to shape the future (Stuart 2010:2) - which sharply distinguished it from the Howard government. Three factors were significant. First, the government came to office with a governance reform agenda that encompassed aspects of the Public Service. Second, there was momentum for change coming out of the Prime Minister's drive for performance and strategic focus across a wide range of policy issues. Third, there was the unleashing of a formal reform process and the resulting 'blueprint' that were associated with the head of the Public Service, Terry Moran.

This chapter first considers the advent of a new government and the contribution that it initially sought to make to machinery and principles of governance, and then examines the launching of a major reform process that produced the blueprint for reform (AGRAGA 2010). Judgments about how this ambitious agenda were worked through in practice can only be provisional, and for this exceptional term indicate the need to differentiate evaluation at the level of ideas and initiatives from those of implementation and practice. The working assumption was that Rudd was guaranteed more than one term and that implementation would continue across several terms. As well there

1 For details, see earlier volumes in this series (Appendix 1.1). 
was the unravelling of the government's policy and program intentions, which cannot be detailed within this chapter, yet they came to overshadow what was accomplished.

\section{The reform trajectory and transitions for the APS}

Where the APS has come from and how it appeared to be travelling during the first term prior to the blueprint are the subjects of this and the following sections. In the first decade of the contemporary reform initiatives (the 1980s), the dominant theme was management improvement. The commitment to neoliberal reforms in the 1990s led the Public Service to become decentralised, marketised, contractualised and privatised-most clearly under the Howard government. A deregulated personnel system and a new financial management framework extended agency devolution. A diminished role for central agencies was one result.

The transition from this approach proceeded in three phases. The first phase (early 2000s) blunted the impact of 'New Public Management' (NPM) and was characterised by less emphasis on competition and outsourcing, responding to new pressures (for example, international threats to security) and a greater focus on effectiveness. A heavy-handed approach to controlling the Public Service was supplanted by more reflection and balance in public management.

The dominant themes of the second phase (mid-2000s) can be summarised as integrating governance. First, central agencies were resurrected through expanding their roles - the Department of the Prime Minister and Cabinet $(\mathrm{PM} \& \mathrm{C})$ in policy coordination, and more prominent roles for other central agencies in espousing principles, and monitoring and guiding budgeting, performance and values. Second, systematic monitoring of implementation was introduced as politicians focused on public perceptions of service delivery, and the Cabinet Implementation Unit was used to ensure delivery of government policies and services. A third element was the rationalisation of public bodies and more direct control for ministerial departments over agencies following a review of the corporate governance of statutory authorities. The fourth element was a whole-of-government approach to working across portfolio boundaries, which was influenced by new priorities and pursued through traditional coordination and instruments such as task forces (Halligan 2006, 2008a; O'Flynn 2009).

The third phase encompassed more extensive integration and capacity building for the Public Service, but as part of the new Rudd government's agenda- 
discussed in the next section. Three factors need to be acknowledged in examining the Australian context. First was the long-term effect of the Coalition government's pursuit of a neo-liberal agenda of NPM involving devolution, outsourcing, privatisation and favouring the private sector (although there were several continuities and a continuation of trends apparent under the previous government).

A second factor was the overall impact of the financial and economic crisis on government budgets and on attitudes towards state intervention. The projected budget surplus in 2008 of $\$ 22$ billion was converted to a deficit as two economic stimulus packages were implemented in 2008-09.

The third factor was the Labor government's agenda. The Rudd government introduced its own interpretation of the issues with new agendas to transform public dialogue, an emphasis on national approaches to improving delivery and performance, and objectives in a range of fields including the APS and governance. Its wide policy agenda covered a 'stronger' and 'fairer' Australia and preparing for future challenges (including in education, health, climate change and water) as outlined in the mid-term progress report (Australian Government 2009). Other agendas such as a national urban policy were also added (Moran 2010a).

\section{The Rudd government's new agenda of institution and capacity building}

The government arrived with an agenda for addressing a number of areas of public governance. In style it was quite different from Howard in the handling of the transition with the Public Service, perhaps reflecting Rudd's earlier experience as chief of staff for a Queensland premier. There was no immediate displacement of departmental secretaries, and the language was one of positive engagement with machinery-of-government changes, signalling new policy emphases - for example: climate change and energy efficiency, and broadband, communication and the digital economy. ${ }^{2}$

In Rudd's response to the national and global environment, he argued for the transition between two epochs and orthodoxies, the latter representing different traditions on the roles of government and the market. Neo-liberalism, which sought to subject the state to private markets, was countered by the conception of a 'social-democratic state' as the best option for developing capacity in which the government funds, regulates and provides services (Rudd 2009a).

2 Detailed lists of creations, changes and abolitions of departments and agencies are included as Appendices to Chapter 4 . 
Several elements envisaged for the future Public Service and government were reinvigorating the Westminster tradition (including an independent and professional public service, merit-based selection, and continuity of employment); policymaking processes based on evidence and a culture of contestability; enhancing strategic policy capability; strengthening integrity and accountability; broadening participation through inclusive policy processes; and service delivery focused on outcomes.

\section{Integrity, accountability and Westminster}

The strength of an administrative tradition grounded in Westminster has been apparent in Australia when governments have overstepped the limits of acceptability (for example, the backlash to the purge of secretaries by the Coalition in 1996, and the response to the role of political advisers in the mid2000s). System correction was again apparent with Labor's initial approach. The Rudd government promised to preserve tradition, which meant that it was able to make changes at the top without incurring public debate about the process. Five new departmental secretaries were appointed within the first 20 months after the 2007 election in a process that involved the movement of 11 senior executives as the government sought to place appropriate officials in significant positions.

The office of John Faulkner, the Special Minister of State, was used to pull together a range of integrity and governance responsibilities under one minister: the Public Service, codes of conduct, privacy and various procedures for handling transparency and accountability (for example, freedom of information and regulations). A new Code of Conduct for Ministerial Staff and Standards for Ministerial Ethics were introduced. ${ }^{3}$

As part of its accountability and integrity agenda, the Rudd government recognised the effect of the increasing numbers and roles of ministerial staff on the relationship between ministers and public servants, and the lack of consideration to formalising their responsibilities. The number of advisers was reduced and their conduct subjected to regulation following Rudd's election (Maley 2010). The new Code of Conduct for Ministerial Staff, introduced in mid-2008, stipulated that 'ministerial staff do not have the power to direct APS employees in their own right and that APS employees are not subject to their direction'. Political advisers were now expected to be accountable where they had a policy role (APSC 2008). Yet ministerial staff numbers grew during the

3 Other measures included establishing a register of lobbyists and new guidelines to cover campaign advertising. 
term as offices sought to handle the demands (and they were formally increased after the 2010 election to cope with the more fluid political environment) (Kerr 2010).

\section{Public service coherence and consolidation: one APS}

The lament across the service - the reasons differing between location and level - was of the limitations of a devolved agency structure. Chief executives and departmental secretaries had control over conditions of employment, which produced substantial variations in salary packages. The head of the Public Service, Terry Moran (2009), asserted that there was 'one-APS, and... we need to bring more meaning to that statement. The APS is not a collection of separate institutions. It is a mutually reinforcing and cohesive whole.' The level of agency and departmental autonomy (see Aulich et al. 2010) had generated some concerns, including those relating to constraints on the mobility of APS officers because of variations between agencies in pay and conditions. The Prime Minister echoed these themes: 'there is a clear need for a stronger collective identity within the APS...There are still too many impediments and disincentives for employees moving between agencies'. He added the need 'to foster a greater sense of cohesion and esprit de corps across the APS' (Rudd 2009b:11, 13).

\section{The demise of designated outsourcing}

One of the strongest symbols of NPM was outsourcing. The Rudd government sought to reduce this dependence, initially by commissioning a UK expert, Peter Gershon, to undertake a review of the use of information and communication technology (ICT). It recommended a 'major program of both administrative reform of, and cultural change from, a status quo' to reduce costs across the APS by $\$ 16$ billion of the annual computer and communications expenditure (Gershon 2008:iii). Legal services were also being brought more in-house following a review.

The government moved to reverse the external reliance by a major reduction in outsourcing of ICT in the Public Service. The goal of the Finance Minister, Lindsay Tanner, was for the number of ICT contractors to be cut by 50 per cent by the end of 2011. Full-time public service staff would replace them. This 'is designed to correct imbalances caused by the previous Government's radical decentralisation of the sector', which derived from the 1997 decision to outsource IT infrastructure services through competitive tendering processes (Tanner 2009). This devolved environment of the public sector was now seen as a key challenge to achieving government outcomes. The decentralised financial managementsystem was perceived to run the risk that the 'government may 
not be fully leveraging its substantial purchasing power to achieve value for money in its procurement...the excessive decentralisation that was embraced by our predecessors inevitably resulted in significant waste, duplication and inefficiencies in the procurement of goods and services' (Tanner 2009).

\section{National integration}

A new phase in intergovernmental relations was initiated with the intention of strengthening vertical relationships within the federation. The reform agenda of the Council of Australian Governments (COAG) was at the forefront of the government's modernisation and policy agenda. The focus on developing intergovernmental relationships and improving national policy and delivery of the federal system was given impetus because, for a time, the same party controlled all nine governments (for detailed coverage of COAG matters, see Chapter 6 of this volume).

At the interface between levels, the Australian Intergovernmental Agreement on Federal Financial Relations was designed to improve the wellbeing of Australians through collaborative working arrangements and enhanced public accountability covering outcomes achieved and outputs delivered. The arrangement provides for accountability at the federal level with state-level flexibility regarding delivery and indicators (APSC 2010).

A secondary dimension has been the argument for extending professional connections across the several public services. The APS is viewed as 'part of a broader professional family of public services'. Modern challenges require working together to give "real voice to the concept of "one-APS" and building a broader professional ethos must involve knocking down barriers which prevent mobility' (Moran 2009).

\section{Performance management and transparency}

Australia has been more committed to performance management than most Organisation for Economic Cooperation and Development (OECD) countries pursuing this agenda since the mid-1980s with increasing refinements. The official model is a fully developed performance-management system based on a framework of outcomes and outputs covering individual and organisational dimensions and management interrelationships (Bouckaert and Halligan 2008; Hawke and Wanna 2010).

As to how performance information was used, the picture was one of both evolution and continuing shortcomings, including variations among agencies in how they engage performance. A review of the Application of the Outcomes 
and Outputs Framework (ANAO 2007) reported variability in descriptions of outcomes and outputs, outcomes and outputs structures, operational integration and use of this information in decision making. In practice, the implementation was not fully realised and officials often worked around the framework rather than through it.

The change of government produced an agenda to improve budget transparency (termed 'Operation Sunlight') that drew on a report by the then Senator Andrew Murray (Tanner 2008). The diagnosis of the existing framework was blunt:

Some outcomes are so broad and general as to be virtually meaningless for Budget accounting purposes leading taxpayers to only guess what billions of their dollars are being spent on...

There is also imprecise reporting of targets and little reporting back against key result areas. Loose outcome descriptions can also foster incentives for money to be shifted between outcomes for political purposes or for spending such as government advertising to be undertaken for overt political purposes without parliamentary approval...

The outcomes and outputs framework was intended to shift the focus of financial reporting from inputs...to outputs and outcomes i.e. actual results. While this is worthy in theory, it has not worked. Basic information on inputs was lost in the changeover, and reporting of outcomes is seriously inadequate. (Tanner 2008:4)

The main objectives included improvements to the outcomes and outputs framework, the readability and usefulness of budget papers and the transparency of estimates (see Operation Sunlight: DoFD 2010).

The Australian response to the limitations of its performance management framework has been to seek improvements to it. Rather than outcomes as a focus being discarded, they remain with augmented features to the framework. Programs were revived for portfolio budget statements and, along with outcomes, form the basis for reporting. Political leaders reinforced a performance focus, and there was greater interest in targets and league tables, and service delivery focused on outcomes. The pursuit of more effective performance management maintains the directional path of 30 years, but it continues to be a work in progress.

\section{Open government}

A declaration of open government was made in mid-2010 with three components: citizen engagement, accessibility of government information and new technology. A new multidimensional culture of 'public sector openness, transparency and 
engagement' was proclaimed, which for citizens was intended to offer prodisclosure, and collaborative (in designing policy and service delivery), engaged (online, the 'collaborative web') and consultative and participative government (AGIMO 2010; Tanner 2010).

The task force's report recommendations on Government 2.0 were accepted (Government 2.0 Taskforce 2009). A concrete result was the creation of the Office of the Information Commissioner, which, with freedom-of-information (FOI) reforms, was thought to be sufficient to restore 'trust and integrity in government' (Tanner 2010).

\section{The Prime Minister and central steering}

This role was reinforced under Rudd following a major organisational audit of the Department of the Prime Minister and Cabinet, which indicated that it was 'heavily focused on the day-to-day activities of government, and that [its] capacity to provide strategic policy advice could be improved' (PM\&C 2008:3). A Strategy and Delivery Division was established to advance administrative priorities that were more strategic, long term and proactive. The overall objective was a strong department for supporting the Prime Minister's reform agenda for the nation with monitoring of progress assuming significance (Halligan forthcoming).

Rudd's leadership approach was close to a 'priorities and planning style' in which first ministers are 'in a strong political position and choose to pursue an ambitious, creative, and comprehensive legislative program' (Campbell 1988:59). This style favours central agencies and their role in 'assembling coherent policies and programs'. Ultimately, a strategic governance form of central steering is dependent on executive leadership, and how the priorities and the planning style are sustained over time.

The indications of the 'court government' reported for Canada, where power has been concentrated in the Prime Minister and 'carefully selected courtiers' (Savoie 2008:16), has relevance to Australia. One issue under Rudd was the extent to which informal processes had displaced formal cabinet decision making. On the one hand, cabinet meetings were reported as having increased 47 per cent in 2008-09, while cabinet committee meetings were up 211 per cent (PM\&C 2009), yet there were consistent reports that a 'kitchen cabinet' of key ministers made key decisions. Moreover, the Prime Minister's office was depicted as having

acquired more comprehensive authority and power. Never, even in John Howard's day has so much power been concentrated in the Prime Minister's private office. Not in his department, although it too is accumulating unprecedented power, but among the tight core of 
minders, advisers and managers focused exclusively on the political survival of the government and the Prime Minister. Above anything else (Waterford 2008:8).

Rudd's reliance on inexperienced political advisers was regarded as a factor in his displacement, and surfaced as an early but transient election issue in 2010.

\section{Blueprint for reform}

With the government's extended agenda of change, it was concluded that there were significant capability weaknesses and a lack of coherent direction for the Public Service to justify the appointment of an advisory group. According to the Prime Minister, 'the next stage of renewal of the APS requires more than just piecemeal change. We need a more sweeping reform driven by a long-range blueprint for a world class, 21st century public service' (Rudd 2009b:12).

The review of the reform of Australian government administration was announced in September 2009 as a six-month process (Rudd 2009a), a discussion paper was released the next month (AGRAGA 2009), and the report Ahead of the Game: Blueprint for the reform of Australian government administration was released in late March 2010 (AGRAGA 2010). The head of the Department of the Prime Minister and Cabinet chaired the advisory group. ${ }^{4}$

Why does Australia have an explicit and fully fledged reform process? Leaving aside Australian state governments and territories that have been running reform agendas in recent years (for example, Western Australia and the Northern Territory), there appears to be nothing comparable internationally. Yet Australia is far less constrained (or crippled) than others by the fallout and large deficits from the global financial crisis, and is not driven by the need to cut the Public Service (by up to 25 per cent for departments in the United Kingdom).

One interpretation is that a party out of power for 11 years might wish to launch a reform agenda in order to differentiate itself from the previous regime, yet the government was already undertaking the reforms discussed earlier. Of direct relevance were the expectations of an activist government, and in particular a prime minister with a highly ambitious policy and reform agenda. The expansive program was already making demands on the Public Service that exceeded capacity and exposed weaknesses. A further explanation that assisted in understanding the rationale for the review was its chair. Terry Moran came from a commonwealth central agency and later ran the Victorian Premier's Department before becoming Secretary of the Department of the Prime Minister

4 For details of the process, see the comprehensive review by Lindquist (2010). 
and Cabinet. Unusually, the new head had both a strong mandate and an understanding of how to manage a large and complex public sector and the systemic requirements and interplay between the elements.

Initially, there was a highly aspirational flavour to the review. The subtitle of the discussion paper was 'Building the world's best public service' (AGRAGA 2009). The paper correctly observed that in most international comparisons, our public service fares very well', but it wanted further improvement: 'Australia's public service can legitimately aspire to be no less than the best public service in the world.' This raised questions about which countries to compare Australia with given its high standing, and how to comprehend what is best practice overall for a civil service. It is difficult to point to specific models of high-performing and quality civil services that offer rounded and relevant options, and there are problems with ignoring the country traditions in which models are embedded (for example, the Nordic emphasis on trust) or government structures (unitary compared with federal systems). Eventually, the review settled for being 'ahead of the game' (AGRAGA 2010).

The actual diagnosis suggests lack of capacity and accountability, a series of deficits (for example, a shortfall in capability), a lack of high performance, and creeping bureaucratisation and compliance issues (termed 'red tape') (AGRAGA 2009, 2010; Rudd 2009b). These tendencies could be seen as reflecting the 'sedimentation' that permeates much recent academic interpretation as the layers of different models of public management are superimposed over time (Halligan 2010).

The review picked up a number of matters already the subject of discussion, debate and reports. The catalogue of items compiled in the blueprint report included efficiency dividends (JCPA 2008), revising APS values (IPAA 2009), reducing red tape (MAC 2007), the roles of secretaries, including stewardship as a response to short-term thinking (on secretaries, see Egan 2009; Halligan 2008a; Podger 2009; Sedgwick 2010), weaknesses in policy making (Banks 2009), and the consequences of different conditions of employment for joint activity (Blackman et al. 2010; Moran 2009).

The blueprint covers 28 recommendations in nine reform areas that are organised under four themes: citizen needs; leadership and strategic direction; capability; efficiency and high standards (Appendix 3.1). By its nature, this is not an exercise that has yet generated innovations that would rank internationally. Centrelink, for example, was originally hailed overseas as a one-stop, multipurpose delivery agency for providing services to several purchasing departments, and for seeking customer-focused delivery that provided integrated services (Halligan 2008 b). This is not to say that innovation will not emerge in the implementation process, and the commitment to being innovative is high (MAC 2010). 
There are, of course, ideas that are new to the APS, but are based on practice elsewhere. The question of relating to citizen engagement has been around for some time (Briggs 2009), but conducting satisfaction surveys has been borrowed from Canada and New Zealand. The capability reviews from the United Kingdom have been adopted, but the concept is being substantially adapted to Australian needs.

Four types or orders of reform can be distinguished. The first-system maintenance - is the most basic and focuses on finetuning and reconditioning. As previously discussed, there was an accumulation of items waiting for the right opportunity to be formalised (cf. Kingdon 1984). Reform enhancementthe second type - is about introducing new instruments and techniques. This includes giving impetus to reform agendas that need a driver-for example, citizen engagement. A third type - system design and maintenance-addresses systemic coherence and balance in which there is systematic refurbishing of the components. This type is in the tradition of a comprehensive review and provides a reform context in which finetuning and new techniques can be introduced.

A fourth, paradigm reform represents a fundamental form of change that subsumes the others, and can be observed in the historic shift to new public management. To put this in a contemporary perspective, the Australian agenda falls well short of the United Kingdom - ever a risk-taker in reform-which could yet produce a case of paradigm change in its radical action in 2010 to reconfigure the public sector. But note that economic conditions are the mother of innovation. The distinctive pathways of the two countries reflect different levels of public spending, the impacts of the economic crisis and the size of their budget deficits.

Australia fits the third type as a large-scale crafting of the system. The influence of Moran as a systemic thinker and operator is important here. He argues that the blueprint for the Public Service is 'more than the sum of the parts' (Moran 2010b).

What is original about the review is the exercise itself, both in the conception of comprehensive design and maintenance and in the execution. The blueprint is a prolegomenon to an extended reform process managed by the Public Service. There is a rolling agenda for change with a large range of elements that encompasses many players (in particular, two leadership groups: a new Secretaries Board and APS 200 - a senior leadership forum for supporting the secretaries).

By the advent of the caretaker period prior to the August 2010 election, numerous processes were under way to implement the blueprint recommendations. 
The most significant was the augmentation of the Australian Public Service Commission's powers by government endorsement of the blueprint. It was made the lead agency for about half the recommendations, with \$39 million allocated under the 2010 budget (although subsequently cut by Prime Minister, Julia Gillard, when projecting fiscal rectitude in the election campaign).

\section{Results of the term}

Several emergent features remain underdeveloped: central steering, public service capacity, flexible delivery and external relationships.

\section{Steering strategically}

Central steering was reformulated under Rudd, who emphasised strategy, policy capability, targeted performance and the design of governance nationally and federally. Rudd's leadership style followed a 'priorities and planning style' (Campbell and Halligan 1992) in which first ministers operate from a position of strength to pursue an ambitious and comprehensive program, which favours the role of central agencies in providing coherence and direction. Following an organisational audit of the Department of the Prime Minister and Cabinet, which indicated the need for improving its capacity to provide strategic policy advice, a Strategy and Delivery Division was established to advance priorities that were more strategic, long term and proactive. The overall objective of a strong department for supporting and monitoring the Prime Minister's reform agenda intensified as the term proceeded.

\section{Internal public service: strengthened but wanting}

The institution of the Public Service has been strengthened by attention to boundaries, political and private sector relationships and traditions. There were, however, high expectations for performance and for improved innovative policy capacity (the subject of a Management Advisory Committee 2010 project that inquired into public sector innovation and an appropriate culture; also ANAO 2009; DIISR 2010). The perceived deficit in capacity was a factor in the Moran review of the Public Service.

\section{Managing flexibly and across boundaries}

The importance of the business case for government initiatives remained and could entail 'market design'. Markets were to be managed to achieve government objectives (the notion of markets as policy instruments that can be managed 
is not new). The Treasurer, Wayne Swan (2008), embraced the use of markets that were 'properly designed and well regulated'. While there were precedents for this approach (for example, the Job Network), the designed and regulated market was used in a range of areas (with Swan regarding commonwealth-state relations as being redesigned using 'a more market-driven framework' that combined incentives and accountability).

\section{External relations with citizens: a work in progress}

A government agenda has been to broaden participation through inclusive policy processes, and the Prime Minister has diagnosed citizen relationships as a field for further attention. This area is challenging for the central-government tier in a federal system, although delivery agencies (for example, Centrelink) have extensive experience. The Government Task Force on Government 2.0 addressed the use of Web 2.0 techniques for supporting community consultation and collaboration (Government 2.0 Taskforce 2009), and this was a feature of the Moran review.

\section{Implications and contradictions of Rudd's governance}

The full implications of these reform strands cannot be examined within one chapter, beyond noting that the government was operating on the assumption of more than one term in office in order to address perceived deficiencies. For the Public Service, the two main leaders - the Prime Minister and his chief official adviser - exercised pivotal influence (not unlike John Howard and Peter Shergold). Rudd displayed the features of a priorities and planning style (before defaulting to electioneering), while Moran deployed the powers of his headship of the Department of the Prime Minister and Cabinet to strengthen its roles and launch a pervasive review of the system. The complementary roles of the political executive and the Public Service leadership are apparent: the political and policy agendas directed by the Prime Minister and the machinery reforms being led by the departmental secretary, although endorsed by the government.

Several issues remained unresolved. First was the question of potential conflicts between objectives that invariably arise with a comprehensive reform agenda. The effect of the Rudd agenda was a doubled-edged sword. On the one hand, it reinforced traditional values: a professional public service and accountability and transparency; while on the other, it was seeking to reduce the size of the service while making heavy demands on public servants and renewing the emphasis on performance. One trade-off was that the consolidation and reaffirmation of Westminster principles meant higher expectations for a modernised public service. 
A second issue was how best to balance the several relationships involved in governing. For example, in addressing the relative roles of line and central agencies, the question was what forms of rebalancing are appropriate. Whereas before the degree of decentralisation was perceived to be problematic, now the matter was more one of curbing potential centralising tendencies.

The contradictions in the Rudd style were a defining feature of the term: the commitment to enhancing the Public Service, against the eventual reliance on court politics of a few advisers (cf. Savoie 2008 on Canada and the United Kingdom); the richness of the array of initiatives, against the lack of consummation under a government thought to be guaranteed a second term. The most disturbing aspect for public governance was the loss of impetus as the Rudd government compromised its agenda in the run-up to the election and experienced acute implementation failure with programs (for example, the rollout of the home insulation program and the Building the Education Revolution program). The Prime Minister forsook policy and planning for short-term opportunism and pragmatism reminiscent of Howard in his last election year (Halligan 2008a), and similarly experienced an annus horribilis. The catastrophic failures of governance climaxed with the replacement of Rudd as Prime Minister and the unexpected retirement of two ministers: John Faulkner, Minister for Defence, and Lindsay Tanner, Minister for Finance - both of whom had played significant roles in reform.

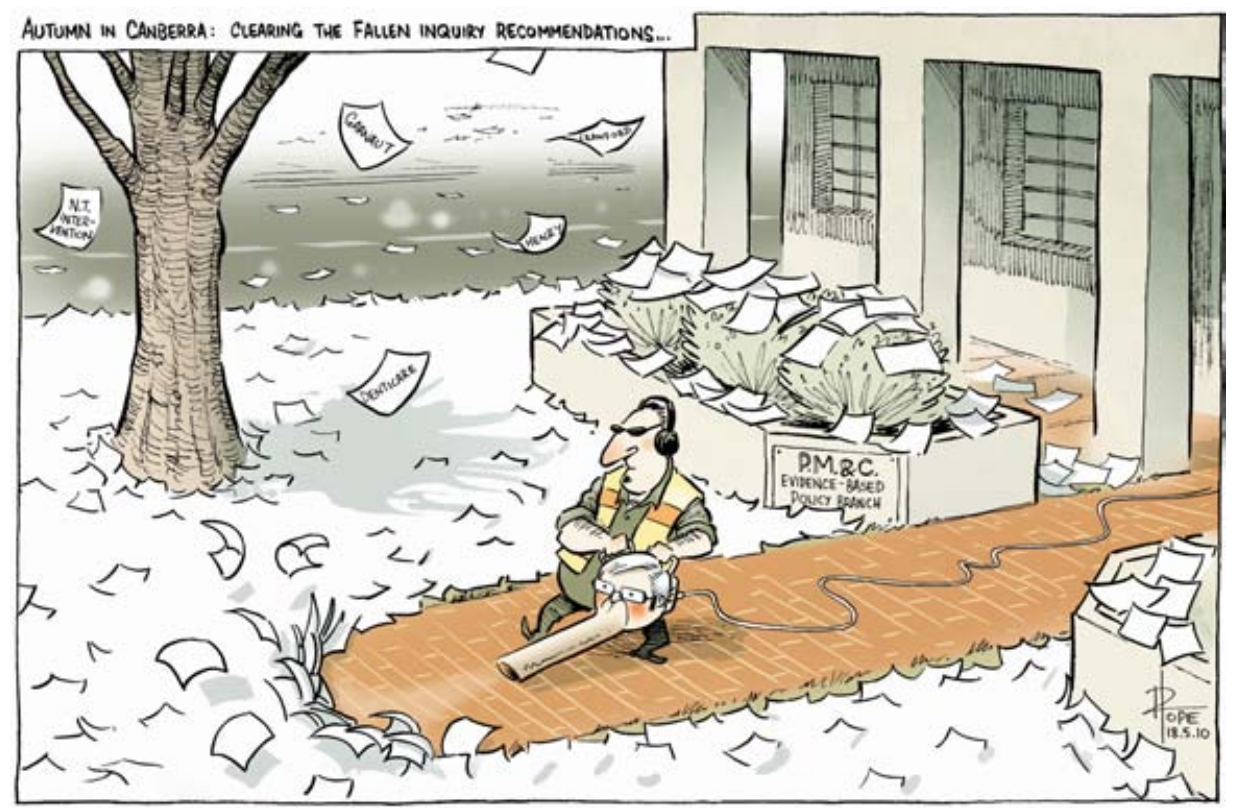

Source: David Pope, The Canberra Times, 18 May 2010 


\section{Conclusion}

Judgments about the Rudd term need to recognise the dimensions presented in this chapter. A number of new measures were articulated and implemented and have contributed to the quality of governance. Others were in process with an indeterminate result and/or were sidelined by the policy and political crises leading up to the election. The blueprint is a medium-term venture that stretches well beyond the present parliamentary term, but this will be subject to the level of funding, which was drastically cut by Prime Minister Gillard during the 2010 election campaign, and to the level of political endorsement and support in her second term.

Stability of office-holding in the transition to power and the common ground between alternative governments have been significant factors in sustaining the trajectory and implementation of Australian agendas in the reform era. Despite a succession of models and variations in the leadership styles of prime ministers' different ideological approaches, the cumulative results have been relatively consistent.

The interpretation in this chapter has taken into account the promise of a reform agenda - much of it unfulfilled - and that its realisation is attendant on how the new Prime Minister envisages the way forward. Much of the blueprint agenda can be pursued by the Public Service if committed leadership exists. Prime Minister Gillard has indicated that the emphasis on the Department of the Prime Minister and Cabinet would be modified under her leadership and with the low funding priority accorded to APS reform, the fate of the reform program (like much of the Rudd term) remains indeterminate.

John Halligan is Professor of Public Administration at the University of Canberra. 
The Rudd Government

\section{References}

Advisory Group on the Reform of Australian Government Administration (AGRAGA) 2009. Reform of Australian government administration: building the world's best public service, Discussion Paper, Commonwealth of Australia, Canberra.

Advisory Group on the Reform of Australian Government Administration (AGRAGA) 2010. Ahead of the Game: Blueprint for the reform of Australian government administration, Commonwealth of Australia, Canberra.

Aulich, C., Batainah, H. and Wettenhall, R. 2010. 'Autonomy and control in Australian agencies: data and preliminary findings from a cross-national empirical study', Australian Journal of Public Administration, vol. 69, no. 2, pp. 214-28.

Australian Government 2009. Mid Term Progress Report, June, Commonwealth of Australia, Canberra.

Australian Government Information Management Office (AGIMO) 2010. Declaration of Open Government, Department of Finance and Deregulation, Commonwealth of Australia, Canberra, <http://www.finance.gov. au/e-government/strategy-and-governance/gov2/declaration-of-opengovernment.html>

Australian National Audit Office (ANAO) 2007. Application of the outcomes and outputs framework, Audit Report No. 23, Australian National Audit Office, Barton, ACT, < <ttp://www.anao.gov.au/uploads/documents/2006-07_ Audit_Report_23.pdf $>$

Australian National Audit Office (ANAO) 2009. Innovation in the Public Sector: Enabling better performance, driving new directions, Australian National Audit Office, Barton, ACT.

Australian Public Service Commission (APSC) 2008. Code of Conduct for Ministerial Staff, Circular 2008/7, Australian Public Service Commission, Canberra.

Australian Public Service Commission (APSC) 2010. Case Study: Australia's new cooperative federal financial agreement: focusing on better outcomes for citizens, Australian Public Service Commission, Canberra.

Banks, G. 2009. Challenges of Evidence-Based Policy-Making, Commonwealth of Australia, Canberra. 
Blackman, D., Buick, F., Halligan, J., O'Flynn, J. and Marsh, I. 2010. Australian experiences with whole of government, Paper presented to Panel Track 32, Working Across Boundaries: Barriers, enablers, tensions and puzzles, IRSPM Conference, University of Bern, April.

Bouckaert, G. and Halligan, J. 2008. Managing Performance: International comparisons, Routledge, London.

Briggs, L. 2009. All Those Who Stand and Wait-Putting citizens at the centre, 21 May, John Curtin Institute of Public Policy,

Curtin University of Technology, Bentley, WA.

Campbell, C. 1988. 'The search for coordination and control: when and how are central agencies the answer', in C. Campbell and B. G. Peters (eds), Organizing Governance: Governing organizations, University of Pittsburgh, Pa, pp. 55-79.

Campbell, C. and Halligan, J. 1992. Political Leadership in an Age of Constraint: Bureaucratic politics under Hawke and Keating, Allen \& Unwin, Sydney.

Department of Finance and Deregulation (DoFD) 2010. Operation Sunlight, Department of Finance and Deregulation, Commonwealth of Australia, Canberra, < <ttp://www.finance.gov.au/financial-framework/financialmanagement-policy-guidance/operation-sunlight/index.html>

Department of Innovation, Industry, Science and Research (DIISR) 2010. Australian Innovation System Report, Department of Innovation, Industry, Science and Research, Commonwealth of Australia, Canberra.

Department of the Prime Minister and Cabinet (PM\&C) 2008. Annual Report 2007-2008, Department of the Prime Minister and Cabinet, Commonwealth of Australia, Canberra.

Department of the Prime Minister and Cabinet (PM\&C) 2009. Annual Report 2008-2009, Department of the Prime Minister and Cabinet, Commonwealth of Australia, Canberra.

Egan, J. 2009. Review of Work Value for the Office of Secretary: Australian government departments of state, Prepared for the Commonwealth Remuneration Tribunal, Sydney.

Gershon, P. 2008. Review of the Australian Government's use of Information and Communication Technology, Commonwealth of Australia, Canberra.

Government 2.0 Taskforce 2009. Engage-Getting on with Government 2.0, Australian Government Information Management Office, Canberra. 
Halligan, J. 2006. 'The reassertion of the centre in a first generation NPM system', in T. Christensen and P. Lægreid (eds), Autonomy and Regulation, Edward Elgar, Cheltenham, UK.

Halligan, J. 2008a. 'Australian Public Service: combining the search for balance and effectiveness with deviations on fundamentals', in C. Aulich and R. Wettenhall (eds), Howard's Fourth Government, UNSW Press, Sydney, pp. $13-30$.

Halligan, J. 2008b. The Centrelink Experiment: An innovation in service delivery, ANU E Press, Canberra.

Halligan, J. 2010. 'Reforming management and management systems: impacts and issues', in P. Ingraham and J. Pierre (eds), Public Change and Reform: Moving forward, looking back: a festschrift to honor B. Guy Peters, McGillQueens University Press, Montreal.

Halligan, J. (forthcoming). 'Central steering in Australia', in C. Dahlström, B. G. Peters and J. Pierre (eds), Steering from the Centre: Central government offices and their roles in governing, University of Toronto Press, Ontario.

Hawke, L. and Wanna, J. 2010. 'Australia after budgetary reform: a lapsed pioneer or decorative architect?', in J. Wanna, L. Jensen and J. de Vries (eds), The Reality of Budgetary Reform in OECD Nations: Trajectories and consequences, Edward Elgar, Cheltenham, UK, pp. 65-91.

Institute of Public Administration Australia, National Council (IPAA) 2009. Submission to the Advisory Group Reform of Australian Government Administration, November.

Joint Committee of Public Accounts and Audit (JCPA) 2008. The efficiency dividend and small agencies: size does matter, Report 413, Commonwealth of Australia, Canberra.

Kerr, C. 2010. 'More work to cope with political paradigm shift', The Australian, 27 September, p. 5.

Kingdon, J. W. 1984. Agendas, Alternatives, and Public Policies, Little Brown \& Co., Boston.

Lindquist, E. 2010. 'From rhetoric to blueprint: the Moran Review as a concerted, comprehensive and emergent strategy for public service reform', Australian Journal of Public Administration, vol. 69, no. 2, pp. 115-51.

Maley, M. 2010. 'Australia', in C. Eichbaum and R. Shaw (eds), Partisan Appointees and Public Servants: An international analysis of the role of the political adviser, Edward Elgar, Cheltenham, UK, pp. 94-113. 
Management Advisory Committee (MAC) 2007. Reducing Red Tape in the Australian Public Service, Commonwealth of Australia, Canberra.

Management Advisory Committee (MAC) 2010. Empowering Change: Fostering innovation in the Australian Public Service, Commonwealth of Australia, Canberra.

Moran, T. 2009. Challenges of public sector reform, Speech to Institute of Public Administration Australia, Canberra, 15 July.

Moran, T. 2010a. City strategic planning, Speech to Council of Capital City Lord Mayors Towards a National Urban Policy Summit, 27 May.

Moran, T. 2010b. Presentation to APS staff by Terry Moran, Secretary of Department of the Prime Minister and Cabinet, Canberra, 21 May.

O'Flynn, J. 2009. 'The cult of collaboration in public policy', Australian Journal of Public Administration, vol. 68, no. 1, pp. 112-16.

Podger, A. 2009. The Role of Departmental Secretaries: Personal reflections on the breadth of responsibilities today, ANU E Press, Canberra.

Rudd, K. 2009a. 'The global financial crisis', The Monthly, February, pp. 20-9.

Rudd, K. 2009b. John Paterson Oration, Australia and New Zealand School of Government Annual Conference, Canberra, 3 September.

Savoie, D. 2008. Court Government and the Collapse of Accountability in Canada and the United Kingdom, University of Toronto Press, Ontario.

Sedgwick, S. 2010. Australian public sector reform, Presentation to 2010 Government Business Conference, 6 May.

Stuart, N. 2010. Rudd's Way: November 2007-June 2010, Scribe, Melbourne.

Swan, W. 2008. Address to the Per Capita Conference, Brisbane, 30 October.

Tanner, L. 2008. Operation Sunlight: Enhancing budget transparency, December, Commonwealth of Australia, Canberra.

Tanner, L. 2009. Address by the Hon. MP Minister for Finance and Deregulation, Public Sector Procurement Conference, Sydney, 28 July.

Tanner, L. 2010. Declaration of open government, Media release, 16 July, Parliament House, Canberra, <http://www.financeminister.gov.au/archive/ media/2010/mr_412010.html >

Waterford, J. 2008. 'On a west wing and a prayer', The Canberra Times, 16 May, p. 8. 


\section{Appendix 3.1}

\section{Nine reform areas and 28 recommendations in the 'Blueprint'}

\begin{tabular}{|c|c|c|c|}
\hline \multicolumn{4}{|c|}{ A high-performing public service } \\
\hline $\begin{array}{l}\text { Meets the needs of } \\
\text { citizens }\end{array}$ & $\begin{array}{l}\text { Provides strong } \\
\text { leadership and } \\
\text { strategic direction }\end{array}$ & $\begin{array}{l}\text { Contains a highly } \\
\text { capable workforce }\end{array}$ & $\begin{array}{l}\text { Operates efficiently } \\
\text { and at a consistently } \\
\text { high standard }\end{array}$ \\
\hline $\begin{array}{l}\text { 1. Delivering better } \\
\text { services for clients } \\
1.1 \text { Simplify } \\
\text { Australian } \\
\text { government services } \\
\text { for citizens } \\
1.2 \text { Develop better } \\
\text { ways to deliver } \\
\text { services through } \\
\text { the community and } \\
\text { private sectors } \\
1.3 \text { Deliver services } \\
\text { in closer partnership } \\
\text { with state, } \\
\text { territory and local } \\
\text { governments } \\
1.4 \text { Reduce } \\
\text { unnecessary } \\
\text { business regulatory } \\
\text { burdens } \\
2 . \text { Creating more } \\
\text { open government } \\
2.1 \text { Enable citizens } \\
\text { to collaborate with } \\
\text { government in policy } \\
\text { and service design } \\
2.2 \text { Conduct a } \\
\text { citizen survey }\end{array}$ & 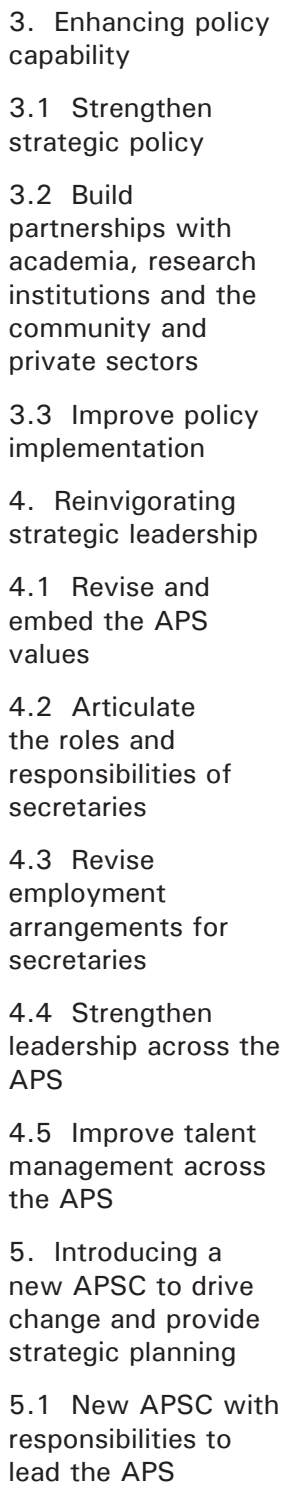 & $\begin{array}{l}\text { 6. Clarifying and } \\
\text { aligning employment } \\
\text { conditions } \\
6.1 \text { Ensure } \\
\text { employment } \\
\text { bargaining } \\
\text { arrangements } \\
\text { support one APS } \\
6.2 \text { Assess the } \\
\text { size and role of the } \\
\text { Senior Executive } \\
\text { Service (SES) } \\
\text { 7. Strengthening the } \\
\text { workforce } \\
\text { 7.1 Coordinate } \\
\text { workforce planning } \\
\text { 7.2 Streamline } \\
\text { recruitment and } \\
\text { improve induction } \\
7.3 \text { Expand and } \\
\text { strengthen learning } \\
\text { and development } \\
\text { 7.4 Strengthen } \\
\text { the performance } \\
\text { framework } \\
7.5 \text { Encourage } \\
\text { employees to } \\
\text { expand their career } \\
\text { experience }\end{array}$ & $\begin{array}{l}\text { 8. Ensuring agency } \\
\text { agility, capability and } \\
\text { effectiveness } \\
\text { 8.1 Conduct agency } \\
\text { capability reviews } \\
\text { 8.2 Introduce shared } \\
\text { outcomes across } \\
\text { portfolios } \\
\text { 8.3 Reduce internal } \\
\text { red tape to promote } \\
\text { agility } \\
9 . \text { Improving agency } \\
\text { efficiency } \\
\text { 9.1 Review the } \\
\text { measures of agency } \\
\text { efficiency } \\
9.2 \text { Strengthen } \\
\text { the governance } \\
\text { framework } \\
9.3 \text { Small agencies } \\
\text { to improve the } \\
\text { efficiency of their } \\
\text { corporate functions }\end{array}$ \\
\hline
\end{tabular}

